\title{
APPLYING THE THEORY OF STIFIn PERSONALITY: INVESTIGATING THE EFFECT OF HR MANAGEMENT PRACTICES ON JOB PERFORMANCE
}

\author{
Yayan Hadiyat ${ }^{1}$, Nina Sri Indrawati ${ }^{2}$, Iswahyudi ${ }^{3}$ \\ 1,2Universitas Pakuan, Bogor, Indonesia \\ ${ }^{3}$ Open University of Indonesia, Jakarta, Indonesia \\ Email: ${ }^{1}$ yayan.h71@gmail.com
}

\begin{abstract}
This article examined the effect of STIFIn-based HR Management Practices on Job Performance. This research is a quantitative study with hypothesis testings using the PLS-SEM approach and analyzed using WarpPLS software. Hypothesis testings are carried out with two models; Model-1 investigates the relationship of the variables in STIFIn HR Management, namely selection and retention of performance. Model-2 investigates the relationship between the overall STIFIn HR management practices and overall job performance. This research was conducted at companies that have implemented STIFIn-based HR Management. The sample was determined by purposive sampling method. This study found a significant effect of STIFIn-based HR Management namely selection and retention practices on employee performance both in task performance and contextual performance. While the results of the model-2 analysis show that STIFIn's overall HR practice is also significant on performance with higher impact than if those HR STIFIn are implemented individually both of selection or retention. The results of this study will provide new insights into the previous research on the effect of HR management practices on performance, and specifically on HR management practices based on employee's personality types.
\end{abstract}

Keywords: STIFIn Personality, HR STIFIn, Selection, Retention, and Job Performance

\section{ARTICLE INFORMATIONS}

Article history: submitted: May 15, 2020; revised: June, 10 2020; accepted: June 15, 2020

JEL Classifiction: J53, M54

How to cited: Hadiyat, Y., et al. (2020). Applying The Theory of STIFIn Personality: Investigating The Effect of HR Management Practices on Job Performance. JIMFE (Jurnal IImiah Manajemen Fakultas Ekonomi), 6(1), 103-122. https://doi.org/10.34203/jimfe.v6i1.2025

Copyright@2020. JIMFE (Jurnal Ilmiah Manajemen Fakultas Ekonomi) Universitas Pakuan

\section{INTRODUCTION}

Human resource management can be a source of the company's competitive advantage because it can find and develop employees more effectively than competitors (Porter, 1985). The competitive advantage comes largely from corporate human resources (Pfeffer, 1994). Research conducted by Koch and McGrath (1996) shows that there is a significant relationship between human resource management and employee productivity. Researchers have paid attention to individual differences to improve performance and productivity. The individual personality factor is one of the micro potentials of the company's competitiveness of human resources (Ployhart, 2012). This is because personality traits affect how people think, feel, and behave (Costa and McCrae, 1992). The behavior itself can be described as performance or one's action which is in line with company goals (Campbell, 1993). Therefore, for HR management and practices to encourage and create employee's performance, more talented employees are needed (Boudreau and Ramstad, 2005).

Theoretically, Jackson and Schuler (1995) and Lado and Wilson (1994), as well as other empirical HRM studies, including Huselid (1995) and MacDuffie (1995), have shown that 
Yayan Hadiyat: Applying The Theory of ...

the methods used by companies to manage their workforce have a positive impact on company performance. These are similar to the results of researches by Becker and Huselid (1998), Delery and Shaw (2001), as well as Wright and Boswell (2002). Personality is an antecedent factor of employee behavior in the workplace which will then affect their other work attitudes such as job satisfaction, organizational commitment, work, intention to quit, and their performance (Truxilo, 2016). Several studies have clarified the benefits of using personality variables to predict employee performance.

Other studies show that personality construction is indeed related to work performance (Barrick and Mount, 1991; Hough, 1992; Salgado, 1997; Tett, et al, 1991). Previous studies that used personality types on the relationship between personality types and performance provided a review of inconsistent results; The study that used the concept of "The Big Five" personality reports only personality conscientiousness that has high validity to predict performance (Barrick and Mount, 1991; Hurtz and Donovan (2000), while the Salgado study (1997) reports that conscientiousness and emotional stability are predictors of performance. The research on MBTI personality types which is conducted in two different cultures, namely in Europe and China, showed the cultural differences seen impacted MBTI personality, but it was not related to job performance. This means that there was a relationship between personality, management style, and management efficacy that may be very different in various cultures, but there was not a relationship with job performance (Furnham and Stringfield, 1993). The research on MBTI personalities also reported that only Intuitive personality and perceiving structures that outperformed preferences for Sensing and Judging, and even the Thinking and Feeling dimensions did not affect the performance of the four service categories (Carr et al, 2002).
The use of personality traits of the Big Five and MBTI models which is based on behavioral characteristics is not a consistent predictor of job performance, hence the need for further study of personality factors on employee performance based on personality types that are naturally possessed by genetics. STIFIn personality types are based on human genetic factors. Several studies that have been conducted show consistent results of the influence of personality factors on employee performance. Researches conducted by Rafianti and Pudjiastuti (2017), Mundiri (2017), Arifin and Gunadi (2017), and Alindra (2018) have proven that the use of the STIFIn personality scheme can consistently produce better performance. This study was conducted to investigate $H R$ management practices based on STIFIn's personalities (Sensing, Thinking, Intuiting, Feeling, and Instinct), especially on job performance. STIFIn's personality is based on the theory that a person will show consistent performance and productivity if they work according to the type of personality that is permanently carried from birth.

\section{LITERATURE REVIEW AND HYPOTHESIS Personality Type and Job Performance}

If a company manages its employees according to their personality types and their potential abilities, then productivity and quality can be improved. Although perhaps research into the type of MBTI personality continues to be a predictor of job performance, it seems to have quite a lot of influence (Da Cunha, 2007), as well as the Borg (1996) study using the MBTI personality type shows that personality types have an important influence on student success. Students whose temperament type matches the class instructor's temperament have significantly better performance results than students whose temperament type does not match the instructor's. Similarly, Bradely and Herbert (1997) and Mazni, et al, (2010) provide evidence that personality types are 
important factors in the performance of successful teams. Organizations that want to develop effective teams need to analyze the composition of the personality types of these groups and help team members understand their attributes and appreciate the contributions of other team members.

However, in other studies conducted with different cultures, such as those conducted by Furnham (1993), the MBTI personality failed to produce a large correlation with performance. The MBTI does not appear to be related to a strong and multifactorial measure of management performance. Likewise, the personality theory of "The Big-Five Personality", although some kinds of literature prove "The Big Five" personality as a predictor of job performance (Bhatti, et al., 2013). Some researches stated that personality measures do not predict job performance consistently. Barrick and Mount (1991) and Hurtz and Donovan (2000) who examined the relationship of the personality of "The Big Five" to job performance (job performance), found only one dimension, namely accuracy (conscientiousness) that is associated consistently with job performance (job performance). There is an allegation submitted on both theories and theories of personality, that their measurements of personality dimensions are dynamic and inconsistent because they use behavioral attributes that can change anytime and can be formed by environmental factors in which a person lives and interacts. The STIFIn personality theory was developed by Poniman (2009) and published in the International Journal of Pshycocial Rehabilitation as the revisited theory of the basic function of personality (Poniman and Amalia, 2020). The theory was developed from the Jungian theory and used authentic approaches to the natural functions and how the brain works along with human actions and behaviors that can be measured by genetic testing tools, such as fingerprint tests, DNA tests, and retinal tests.
Several studies conducted by Rafianti and Pudjiastuti (2017), Mundiri (2017), Arifin and Gunadi (2017), and Alindra (2018) have proven that the use of STIFIn personality can consistently produce better work performance. In particular, Poniman and Hadiyat (2015) in their book "Management of HR STIFIn", provides propositions of observations and experiences during the author's work, namely the positive influence of the application of the STIFIn intelligence engine scheme in HR Management practices can increase productivity. One who works in any field that is under the workings of the intelligence engine will feel comfortable and can provide continuous and permanent productivity. This study will examine the application of a model of human resource management practices that are based on basic human characteristics, namely STIFIn (Sensing, Thinking, Intuiting, Feeling, and Instinct) to produce productivity permanently and consistently or continuously.

\section{STIFIn Personality Theory}

People in the company are the key to success in achieving the company's vision and strategy. Humans are subjects who have basic potential and characters that are carried from birth which will later determine individual productivity and aggregately, will determine the productivity of the company. Ned Hermann (1989) in his journal "The Creative Brain" on the theory of the brain quadrant explained the indications of brain characteristics that had an impact on how to think and how to learn. The brain is very soft and it has almost no inherent obstacles which are attached to it. The whole-brain has access to each hemisphere of the brain and some parts of the dominant brain specify preferences for ways of thinking and learning. The theory of STIFIn personality focuses on only one dominant intelligence machine, this theory also refers to the view of analytical psychologist Carl Gustav Jung (1946), an 
Yayan Hadiyat: Applying The Theory of ...

analytical psychologist, who states that among all basic human functions or intelligence machines, there is only one dominant. According to Jung, the basic functions of human personality are divided into four types, namely; sensing function (Sensing, abbreviated S), mind function (Thinking abbreviated T), feeling function (Feeling abbreviated F), intuition function (Intuiting abbreviated 1), and in the STIFIn theory (Poniman and Amalia, 2020) added the Instinct intelligence machine, abbreviated as 'In', which focuses on instinctive and spirituality functions.

This research, which has been conducted for three years from 2006 to 2019, about human intelligence, provides a thesis that every person has a single dominant intelligence that has been carried out since birth (Poniman, 2009). The theory relies scientifically on the analytical psychological approach pioneered by Jung (1946), compiled with the theory of The Whole-Brain Theory from Ned Herrmann (1989) and the Triune Brain theory developed by Paul McLean. The initial paradigm used is analytical psychology. Forging one's people uses a humanistic behavioral approach. Humans are considered to have extraordinary genetic potential. When this potential gets the right and planned environment and 'forging', the results that come out, in the end, will be extraordinary.

Table 1. Brain Intelligence and Personality Types

\begin{tabular}{llll}
\hline $\begin{array}{c}\text { Basic Function (Carl } \\
\text { Gustav Jung) }\end{array}$ & $\begin{array}{c}\text { Intelligence Type } \\
\text { (Ned Herrman) }\end{array}$ & $\begin{array}{c}\text { Triune Brain (Paul } \\
\text { MacLean) }\end{array}$ & $\begin{array}{l}\text { Personality Type } \\
\text { (Farid Poniman) }\end{array}$ \\
\hline Sensing & Left Limbic & Mammal Brain & Sensing \\
\hline Thinking & Left Neocortex & Human Brain & Thinking \\
\hline Intuiting & Right Neocortex & Human Brain & Intuiting \\
\hline Feeling & Right Limbic & Mammal Brain & Feeling \\
\hline- & - & Reptile Brain & Instinct
\end{tabular}

Source: STIFIn Personality Grand Theory (Poniman \& Amalia, 2020)

The theory of STIFIn Personality by Poniman and Amalia (2020) that the four basic functions of Jung are related to Ned Herrman's creative thinking theory of the brain quadrant, so the four basic functions are nothing but character traits that are eternal, unchanging, which are sourced from the most commonly used hemispheres. The left quadrant of the cerebrum (left neocortex) is both the intelligence and personality characteristics of Thinking ( $T$ ). The right big brain (right neocortex) is Intuiting (I). The left quadrant of the cerebellum (left limbic) is both the intelligence and personality characteristics of Sensing (S). The right small brain (right limbic) is both intelligence and Feeling (F) personality character. Thus, Jung's basic function has similarities to Ned Herrman's brain quadrant. Meanwhile, the fifth intelligence, instinct, arises because there are people who do not tend to fall into all the four categories of personality traits offered by Jung and Ned Herrman or other researchers. This tendency dominantly uses other hemispheres, namely the instinctive brain that is located in the middle or bottom (hindbrain and midbrain), and it is directly connected to the spine. The fifth intelligence-Instinct (I), lies in the combined function of the cerebellum, medulla, midbrain, pons, and the brain organization (The Functional Organization of the Brain), which response quickly to something.

In the STIFIn theory, there is something called 'the steering wheel', namely introvert and extrovert. The introvert's direct intelligence from the inside to outside, whereas the extroverts direct intelligence from the outside to inside. In addition to Instinct (In) intelligence, each intelligence has 
two steerings; Sensing (S) consists of Introverted Sensing (Si) and Extroverted Sensing (Se); Thinking consists of Introverted Thinking (Ti) and Extroverted Thinking (Te); Intuiting and Feeling each consists of Introverted Intuiting (li), Extroverted Intuiting (le), Introverted Feeling (Fi), and Extroverted Feeling (Fe). So there are nine types of personality that come from four intelligence machines after being affixed by the steering wheel plus the Insting (I) intelligence machine. The nine personality types are $\mathrm{Si}, \mathrm{Se}, \mathrm{Ti}, \mathrm{Te}, \mathrm{li}$, $\mathrm{le}, \mathrm{Fi}, \mathrm{Fe}$, and In.

Each type of personality has its main characteristics. People who have the personality of the Introverted Sensing can remember that exceeds eight other personalities. Their personality is based on five senses. They have strong stamina, they work efficiently, they are disciplined, and show details, they are also frugal, if they are asked to help, they will prefer to spend their energy rather than money. This happens maybe because people who have this personality collect money little by relying on volume, not from the margin. While People who have Extroverted-Sensing intelligence have a more generous personality and they tend to be more extravagant, more relaxed and like to have fun, they also like to show off or demonstrative. Their ability to remember is extraordinary, and they can visualize it in detail. They like gifts or sources of motivation in the form of gifts.

As for People who have the IntrovertedThinking intelligence, they have independent personalities, focus on work, and impose high standards on work results. They are not a mediocre type. If they pursue something, they will focus until they reach the level of expertthey do not want to work halfway through. In general, they have good analytical skills. They love to read-which makes them always dominate the problem. On the other hand, people who have the Extroverted-Thinking type have personalities that are reflected in actions such as react immediately when they encounter injustice, judge objectively, accepts people's arguments with logic, they are systematic in working and enjoy formality. People with Introverted-Intuiting personality, among others, are more concerned with quality, rather than quantity. They always emphasize perfection. They are satisfied with things that are new or innovative. They are stubborn and always fight for their wills because they have an optimistic outlook. Everything is seen from whether it provides benefits or not. While people with Extroverted-Intuiting type have personalities, which are reflected in actions such as; always take risks, they have many ideas. They are romantic and inspire the environment. As for people with Introverted-Feeling types have personalities which are reflected in actions such as; they are visionary, bossy, helper, sociable, smart to say, idealistic and sensitive-they get hurt quickly. On the other hand, people who have the ExtrovertedFeeling type, if compared to people with other intelligence, have social spirit. They can galvanize people, they are subjective, brave, always take risks. They are highly tolerant, and they have empathy. People who have the last intelligence-the Instinct (In) intelligence, do not like conflicts. They are sincerely sacrificing for others. Their way of thinking is simple and accommodating.

Everyone has a single dominant intelligence that has been carried out since birth. Humans are considered to have extraordinary genetic potential. The left quadrant of the cerebrum (left neocortex) is the intelligence of the Thinking $(T)$ personality type. The right big brain (right neocortex) is the intelligence of the Intuiting personality type. The left quadrant of the cerebellum (left limbic) is the intelligence of the Sensing (S) personality type. The right small brain (right limbic) is the intelligence of the Feeling (F) personality type. The fifth intelligence does not belong to all the four categories of 
Yayan Hadiyat: Applying The Theory of ...

personality traits, but predominantly uses another brain hemisphere, namely the instinctive brain in the middle or bottom (hindbrain and midbrain)-which is directly connected to the spine. The fifth intelligence is called as the 'Instinct (I)'. It lies in the combined function of the cerebellum, medulla, midbrain, pons, and brain functions (The Functional Organization of the Brain). People with the Instinct (I) personality type are more responsive-they are faster in responding to problems.

\section{HR STIFIn Management and Job Performance}

There have been many studies conducted on the effect of HR Management systems and practices on company performance (firm performance), as well as on employee performance. Glaister, et al, (2016) which examines HR management strategies and business alignment, reports the influence of HR strategy in improving company performance. However, this influence does not become an essential component concerning talent management practices and job performance. HR management practices on employee performance are more influenced by individual character and personality. Bowen and Ostroff (2004) in his article "Understanding HRM-Firm Performance Linkages: The role of the strength of the HR system", reports that the HR management system can explain how the accumulation of individual employee attributes influences organizational effectiveness.

The study of the relationship between personality traits and job performance has been done by several researchers, among others, namely, the research of Lado and Alonso (2017), who investigated the relationship between personality traits and job performance by using job complexity moderating variables. Then, Leena and Kirupa's study (2016); Askarian and Eslami (2013) who conducted a study of the influence of personality type characteristics on job performance, and Kim and Han's research (2014) which showed that the level of academic achievement and student satisfaction differed according to their MBTI personality types. Ciorbea and Pasarica (2012) state that understanding big five personality traits accurately has a profound effect on academic performance and has broad implications for the world of education. Another study of personality trait as a moderating variable "honesty-humility trait" or Hexaco model of personality on the relationship between job insecurity and counter-productive works behavior (Chirumbolo, 2014).

However, research conducted by Furnham (1993) on MBTI personality failed to produce a large correlation with performance. The MBTI does not appear to be related to a strong and multi-factorial measure of management performance. As an addition to the MBTI, the personality theory of "The BigFive Personality", although some literature proves the personality of "The Big Five" as a predictor of job performance (Bhatti, et al., 2013), by many researchers that personality measures do not predict job performance consistently. Like Barrick and Mount (1991) and Hurtz \& Donovan (2000) who examined the relationship between the personality of "The Big Five Personality" and job performance, found only one dimension, namely conscientiousness that was associated consistently with job performance. This study will investigate the practice of $H R$ management using the STIFIn personality type developed by Poniman (2009) on improving job performance.

The Management of HR STIFIn, as defined in the STIFIn HR Management Book (Poniman and Hadiyat, 2015), is the practice of human resource management using the scheme of intelligence machines or STIFIn personality types in the three main activities of human resource management, namely 1) Selection, which includes in planning labor, as well as employee recruitment and selection 
activities; 2) Retention, which includes performance management, fee management, industrial relations and leadership; and 3) Development, which includes training and development activities, and also career development. The theory of STIFIn HR is to attract and select the best people, utilize the best retention systems and programs, and provide a way for them to be able to give their best contribution. In workforce planning, all types of work are mapped and grouped based on the characteristics of STIFIn personality, so that the search or recruitment of labor is adjusted to the needs of the placement of workers which have been mapped to the needs of the STIFIn personality type. Then, the selection process is carried out using the STIFIn personality scheme as well. In utilization and retention activities, the application of HR STIFIn focused on the application of STIFIn's personality in the preparation of performance management systems, reward systems, industrial relations management, and leadership development. Meanwhile, the application of STIFIn HR in training and development activities and career development are focused on the process of developing talent and career development through the process of training analysis, as well as the application of learning methods and training methods to suit the STIFIn personality types. Manpower planning with the STIFIn personality scheme is focused on job analysis, identification of skills, and competencies needed in it. These planings are then outlined in the job description that has identified the suitability of the STIFIn intelligence engine. The job description then becomes the basis for the recruitment and selection process that can improve employee performance after they enter the company and work in the company. In HR management practices, recruitment, and selection activities can predict employee performance significantly (Jouda, et al, 2016). In the application of the STIFIn personality type, the research from Rafianti, et al. (2016) in 15 students of Serang 2 High School, Banten, proved that the STIFIn intelligence scheme could predict results in mathematical abilities.

The practice of STIFIn HR management in the utilization of human resources and retention programs is reflected in actions such as; develop a performance management system based on the STIFIn personality type scheme, compile a reward system that is associated with the STIFIn personality type, industrial relations management both in relationship creation and relationship building industrial and trade union based on the mapping of personality types and relationship patterns of STIFIn personality types, as well as leadership development that uses the basic STIFIn personality types in building leader relationships and followers. Several studies related to the system and practice of human resource management in the activities of STIFIn HR management have proven that there is a significant influence on employee performance. Wambua and Karanja (2016) in their study provide evidence of the influence of the practice of fee management, and the assessment of performance on a significant positive effect on employee performance. Then the proposition which is proposed by Poniman and Hadiyat (2015) in their book "STIFIn HR Management" is a positive influence between STIFIn HR management practices with employee performance.

Business strategy and its implementation in human resource management depend on the quality of its human resources. These qualities are related to the knowledge, skills, and abilities of employees toward the assigned work and tasks, as well as the behavior and mental attitude of employees about how to behave by company values, and to actively participate in achieving the achievement of company goals. The practices of HR STIFIn management for development are training and development activities, as well as employee 
career development. Hassan (2016) revealed that there is a positive and significant relationship between human resource management practices on compensation, career planning, performance appraisal, training, and employee engagement with employee performance. The proposition of Poniman and Hadiyat (2015) proposes that the application of training and development programs, as well as employee career development based on employee personality types, will improve employee productivity and performance. In this study, development activities are not hypothesized by themselves but are combined into retention activities.

Job performance is defined as the completion of tasks with the application of knowledge, skills, and abilities. The article of Ramawickrama, et al (2017), namely "The behavioral outcome of an employee which points out employee is showing positive attitudes towards his or her organization" said that the results of an employee's behavior show a positive attitude towards the organization ". Based on literature studies, job performance (job performance) has been widely researched and defined. Porter and Lawler (1974) define job performance as a function of the abilities, skills, and effort of a person or individual in a situation. Then Campbell (1990) defines job performance as a behavior or action from someone relevant to organizational goals, and Opata (2015), defines job performance as the extent to which employees carry out their duties and responsibilities, and the results are measured by the criteria of quantity of work and quality of work.

This construction of job performance will be used in this study, which then uses the dimensions and indicators that will be derived in the items from the Koopmans et al (2014) study, namely: 1) Task Performance; and 2) Contextual Performance. The dimensions of Counter-productive Work Behavior are not used in this study with the consideration that it is not suitable for cultural conditions in Indonesia, where a person may not be very comfortable if he has to fill out a survey questionnaire containing negative statements so that there will be bias in the survey results. Borman and Motowidlo (1993) define Task Performance as the effectiveness used by officeholders to carry out activities that contribute to the organization's technical core, either directly by implementing part of the technological process, or indirectly by providing needed materials or services, such as tasks performance on Sales jobs which are product knowledge, closing the sale, time management. Whereas contextual performance relates to the contribution to the effectiveness of the organization in ways that shape the organizational, social, and psychological context that catalyzes the activities and processes of carrying out tasks. 
Model 2 (H5)

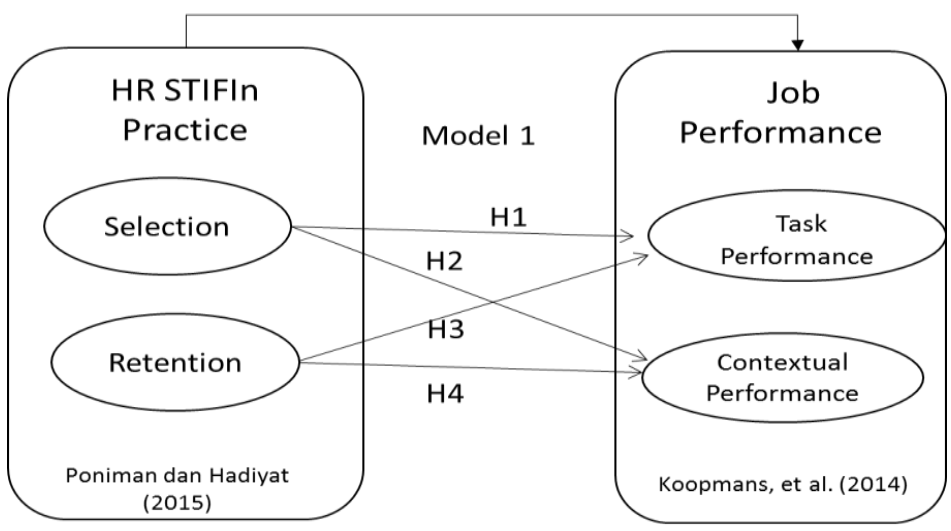

Figure 1. The Research's Theory Model

Source: Data was processed and conducted by the researcher, 2018

The theoretical model of this research is presented in Figure 1. Model 1 investigates the relationship of variables in HR STIFIn Management, namely selection activities (X1) and Retention (X2), as exogenous variables with variables on job performance, namely Task Performance (Y1) and Contextual Performance (Y2). Model 2 was made to investigate the relationship of overall $H R$ STIFIn Management practices (X1) to overall job performance (overall job performance) (Y1). Tests on both of these models are expected to provide different empirical views and evidence, namely to acknowledge the effect of the STIFIn HR management practices carried out in each activity, and if it is carried out as an integration program on job performance both for their dimensions and overall job performance.

Based on the literature reviews and the above research model, the following hypotheses can be formulated as:

\section{Model 1}

Hypothesis 1: Selection of HR STIFIn-based influences on Task Performance

Hypothesis 2: Selection based on HR STIFIn influences Contextual Performance

Hypothesis 3: Retention based on HR STIFIn affects Task Performance
Hypothesis 4: Retention based on HR STIFIn influences Contextual Performance

\section{Model 2}

Hypothesis 5: Practice of STIFIn HR fully influences Job Performance

\section{RESEARCH METHOD}

This research uses a quantitative approach. The technique of collecting data using the survey method is by distributing an online questionnaire through google survey to $H R$ practitioners, covering 34 items of closed statements, using a 5-point Likert Scale, with 1 being Strongly disagreed (STS) and 5 being Strongly agreed (SS). The unit of analysis of this study is individual employees in companies that practice HR STIFIn. The sampling technique in this study was purposive sampling, namely companies that have implemented HR STIFIn Management. A total of 100 respondents were contacted personally via Whatsapp media sharing (WA) and were asked to participate in online questionnaires that had been shared with each respondent.

The measurement of employee performance variables adapts work performance measurements, developed by Koopmans (2014), such as "I like to bear extra 
Yayan Hadiyat: Applying The Theory of ...

responsibility" and add new statement items that fit the context of the intelligence machines through the mechanism of expert approval of the questionnaire compilation. Examples of these items are "I can use the potential intelligence engine that $I$ have to work well in this organization/company". While the variable measurements of the STIFIn HR Practice modify the measurements of HighPerformance Human Resource Practice Perceptions developed by Kehoe and Wright (2010). An example of this item is "The recruitment and selection process is carried out with the STIFIn scheme".

The data analysis technique uses Partial Least Square Structural Equation Modeling (PLS-SEM). The selection of PLS-SEM is because this study is more predictive, and it explains latent variables rather than testing a theory. The number of samples in this study is not high and anticipates if the data is distributed abnormally (Hair et al., 2014). This study uses two research models, where model 1 aims to examine the effect of each dimension of the STIFIn HR Practice on the dimensions of employee performance partially. While model 2 aims to examine the influence of the constructs of the HR STIFIn Practice in a multidimensional manner towards the construct of employee performance in the form of multidimensional.

\section{RESULT AND DISCUSSION}

\section{Characteristics of Respondents}

The purpose of this analysis is to find out the characteristics of respondents in general, where the respondents in this study are employees who work for companies that have practiced HR STIFIn. Out of the total of 100 respondents who were asked to fill out the questionnaire, only 50 people were willing to fill in (response rate $50 \%$ ), after the selection, only 41 answers were obtained that were feasible to analyze. Based on data which were obtained from 41 respondents, it was found that the majority of respondents were male (61\%), and the majority of respondents were Thinking personality type (26.8\%). The majority of respondents had controllers (the steering) of extroverted personality (63.4\%), the majority of respondents have S1 education $(63.4 \%)$, the majority of respondents are aged between $36-45$ years (34.1\%), the majority of respondents have a tenure of 1-5 years $(53.7 \%)$, the majority of respondents are married (75.6\%), and the majority of respondents work for companies that have applied STIFIn HR for 1-5 years (48.8\%). 
Table 2. Respondents' Profile Statistics

\begin{tabular}{|c|c|c|c|}
\hline Demographics & Characteristics & Frequency & Percentage (\%) \\
\hline \multirow{2}{*}{ Sex } & $\mathrm{L}$ & 25 & 61 \\
\hline & $P$ & 16 & 39 \\
\hline \multirow{5}{*}{$\begin{array}{c}\text { Personality } \\
\text { Type }\end{array}$} & Sensing & 8 & 19.5 \\
\hline & Thinking & 11 & 26.8 \\
\hline & Intuiting & 7 & 17.1 \\
\hline & Feeling & 9 & 22 \\
\hline & Insting & 6 & 14.6 \\
\hline \multirow{2}{*}{ Drive } & Ekstrovert & 26 & 63.4 \\
\hline & Introvert & 15 & 36.6 \\
\hline \multirow{5}{*}{ Age } & $<25$ years & 9 & 22 \\
\hline & $26-35$ years & 13 & 31.7 \\
\hline & $36-45$ years & 14 & 34.1 \\
\hline & $46-55$ years & 5 & 12.2 \\
\hline & $>55$ years & 0 & 0 \\
\hline \multirow{2}{*}{ Marital Status } & Married & 31 & 75.6 \\
\hline & Unmarried & 10 & 24.4 \\
\hline \multirow{4}{*}{ Education } & SMA & 6 & 14.6 \\
\hline & D3 & 1 & 2.4 \\
\hline & S1 & 26 & 63.4 \\
\hline & S2 & 8 & 19.5 \\
\hline \multirow{3}{*}{$\begin{array}{c}\text { Length of } \\
\text { HR STIFIn } \\
\text { Implementation }\end{array}$} & $<1$ years & 14 & 34.1 \\
\hline & $1-5$ years & 20 & 48.8 \\
\hline & $<5$ years & 7 & 17.1 \\
\hline \multirow{4}{*}{ Work Service } & $<1$ years & 11 & 26.8 \\
\hline & $1-5$ years & 22 & 53.7 \\
\hline & $6-10$ years & 3 & 7.3 \\
\hline & $>10$ years & 5 & 12.2 \\
\hline
\end{tabular}

\section{Model Test}

\section{Outer Model (Model-1)}

Before analyzing the structural model, the measurement model must be done first. This is intended to test the reliability and validity of the indicators forming the latent construct, namely by conducting confirmatory factor analysis (CFA). In model 1 , the confirmatory analysis of first-order will be carried out, namely testing latent constructs with the indicators. In terms of reliability indicators, out of the 19 indicators in the second processing (in the first processing there are 34 indicators), all of them have a loading factor $>0.70$. The rule of thumb used to assess loading factors is that it must be greater than 0.70 for confirmatory research, and the loading factor value between $0.60-0.70$ is still acceptable for exploratory studies (Latan \& Ghozali, 2017). The following table 5 presents the results of the confirmatory factor analysis of the first order. 
Yayan Hadiyat: Applying The Theory of ...

Tabel 3. Confirmatory Factors Analysis of First Order

\begin{tabular}{|c|c|c|c|c|c|c|c|}
\hline Indikator & $\begin{array}{l}\text { Factor } \\
\text { Loading }\end{array}$ & $\begin{array}{l}\text { Latent } \\
\text { construct }\end{array}$ & $\begin{array}{l}\text { Composite } \\
\text { Reliability }\end{array}$ & $\begin{array}{l}\text { Cronbach's } \\
\text { Alpha }\end{array}$ & AVE & $\begin{array}{l}\text { Square } \\
\text { root } \\
\text { AVE }\end{array}$ & $\begin{array}{l}\text { Full } \\
\text { collin. } \\
\text { VIF }\end{array}$ \\
\hline S1 & 0,844 & \multirow{4}{*}{$\begin{array}{l}\text { Selection } \\
\text { (HR STIFIn) }\end{array}$} & \multirow[t]{4}{*}{0.901} & \multirow[t]{4}{*}{0.853} & \multirow[t]{4}{*}{0.694} & \multirow[t]{4}{*}{0.833} & \multirow[t]{4}{*}{1.95} \\
\hline S2 & 0,829 & & & & & & \\
\hline S3 & 0,857 & & & & & & \\
\hline S4 & 0,801 & & & & & & \\
\hline R1 & 0,829 & \multirow{7}{*}{$\begin{array}{l}\text { Retention } \\
\text { (HR STIFIn) }\end{array}$} & \multirow[t]{7}{*}{0.963} & \multirow[t]{7}{*}{0.955} & \multirow[t]{7}{*}{0.788} & \multirow[t]{7}{*}{0.888} & \multirow[t]{7}{*}{2.573} \\
\hline R3 & 0,871 & & & & & & \\
\hline R5 & 0,808 & & & & & & \\
\hline R6 & 0,921 & & & & & & \\
\hline P2 & 0,944 & & & & & & \\
\hline P3 & 0,924 & & & & & & \\
\hline P4 & 0,907 & & & & & & \\
\hline K1 & 0,748 & \multirow{4}{*}{$\begin{array}{c}\text { Task } \\
\text { Performance }\end{array}$} & \multirow[t]{4}{*}{0.890} & \multirow[t]{4}{*}{0.835} & \multirow[t]{4}{*}{0.670} & \multirow[t]{4}{*}{0.818} & \multirow[t]{4}{*}{2.998} \\
\hline K2 & 0,847 & & & & & & \\
\hline K4 & 0,813 & & & & & & \\
\hline K5 & 0,86 & & & & & & \\
\hline K11 & 0,879 & \multirow{4}{*}{$\begin{array}{l}\text { Contextual } \\
\text { Performance }\end{array}$} & \multirow[t]{4}{*}{0.902} & \multirow[t]{4}{*}{0.853} & \multirow[t]{4}{*}{0.698} & \multirow[t]{4}{*}{0.835} & \multirow[t]{4}{*}{2.642} \\
\hline K12 & 0,885 & & & & & & \\
\hline K14 & 0,845 & & & & & & \\
\hline K15 & 0,722 & & & & & & \\
\hline
\end{tabular}

Based on the results of processing the data, Tabel 3. shown that all items forming the latent construct are valid, with the resulting factor loading value $>0.7$. Furthermore, in convergent validity, the AVE (average variance extracted) value for each dimensional construct is very good at $>0.5$ so that it meets the convergent validity criteria. Likewise, with internal consistency, the composite reliability value produced by each dimensional construct is also very good, namely $>0.7$ and the value of Cronbach's Alpha $(\alpha)$ is between $0.835-0.955$, which means that the reliability value generated by each latent construct is also very good $>0.7$, thus meeting internal consistency reliability. The value of Full Collinearity VIF for each latent construct is also very good, which is $<3.3$ so there is no collinearity problem in the model. Furthermore, reflective indicators forming latent constructs in the study will also be tested by discriminant validity. One way to look at discriminant validity is by comparing the correlation between variables with the square root of variance extracted (the value of the square root $A V E$ ). Table 4 below describes discriminant validity from this study (model 1 ).

From table 4 . it can be seen that all correlation values between variables (latent constructs) are below the AVE square root value (see with a diagonal line, marked ${ }^{\prime \prime \prime}$ ). Thus, it can be concluded that all variables meet discriminant validity criteria, and can be said to be a very good model. A high discriminant validity value provides evidence that a construct is unique and completely different from other constructs, and can capture the measured phenomenon. In short, the measurement model successfully passed some rigorous analyzes, namely convergent validity, discriminant validity, reliability, and multicollinearity. The results of the CFA analysis reveal that the model does not have a data measurement problem because it has fulfilled the criteria of validity which have 
been widely accepted and thus, the data can be analyzed further.

Tabel 4. Discriminant Validity of Model 1

\begin{tabular}{lcccc}
\hline & Selection & Retention & $\begin{array}{c}\text { Task } \\
\text { Performance }\end{array}$ & $\begin{array}{c}\text { Contextual } \\
\text { Performance }\end{array}$ \\
\hline Selection & $0.833^{*}$ & & & \\
\hline Retention & 0.640 & $0.888^{*}$ & & \\
\hline $\begin{array}{l}\text { Task } \\
\text { Performance }\end{array}$ & 0.624 & 0.734 & $0.818^{*}$ & \\
\hline $\begin{array}{l}\text { Contextual } \\
\text { Performance }\end{array}$ & 0.622 & 0.682 & 0.753 & $0.835^{*}$ \\
\hline
\end{tabular}

\section{Inner Model Results (Model-1)}

Based on the results of the general result of the SEM-PLS using WarpPLS 6.0 software, it is known that the model has a good fit, where the P-value values for Average Path Coefficient (APC), Average R-squared (ARS), and Average Adjusted R-squared ( AARS) $<0.001$ with APC value $=0.430$, ARS $=0.608$, and AARS $=0.587$ Likewise, with the Average block value of VIF (AVIF) and Average Full Collinearity VIF (AFVIF), the ideal value is $A V I F=1,646$, and
AFVIF $=2,966(<3,3)$, which means that there is no multicollinearity problem between each indicator and between each exogenous variable. The result of GoF is $0.649>0,36$ which means that the model fit is good. For the Symson's Paradox (SPR) index, R-squared Contribution Ratio (RSCR), Statistical Suppression Ratio (SSR), and Nonlinear Bivariate Causality Direction Ratio (NLBCDR) produce values equal to 1 , which means that there are no causality problems in the model.

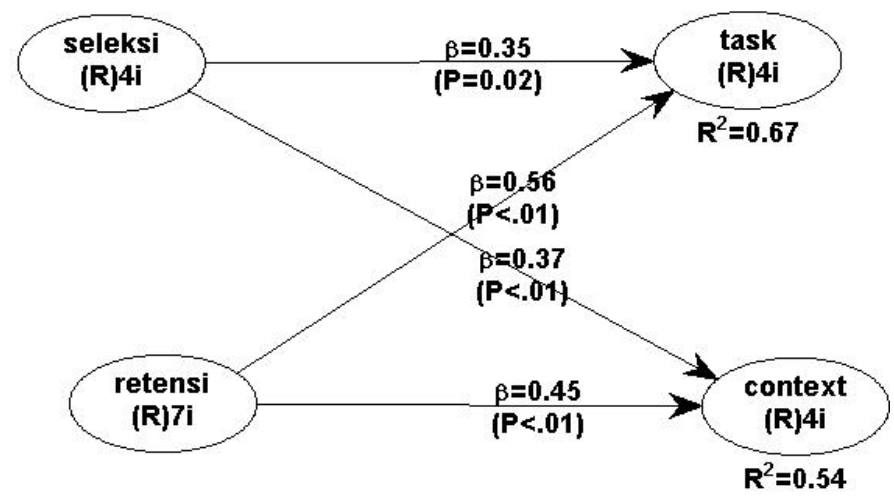

Figure 2. Model 1's Structural Model Analysis

The results showed that the adjusted Rsquared was $0.658(65.8 \%)$, this means that large dependent latent variables (task performance) were explained at $65.8 \%$ by 2 independent latent variables (selection and retention) and the remaining $34.2 \%$ is explained by other variables outside the model. Meanwhile, the Adjusted R-squared coefficient for contextual performance is
0.516 (51.6\%), which means that 2 selection and retention variables can explain contextual performance variations of $51.6 \%$, the remaining $48.4 \%$ is explained by other variables outside the model. The $\mathrm{Q}$-squared value (Q2) produced for each dependent variable (endogenous) > 0 , namely Q2 selection $=0.674$ and Q2 retention $=0.536$, 
Yayan Hadiyat: Applying The Theory of ...

which means that the model has predictive relevance.

Figure 2 and table 5 explain the results of hypothesis testing (path analysis), which shows that the election results have a positive and significant effect on task performance $(\beta=$ $0.345, p=0.017)$, toward the contextual performance $(\beta=0.369, p=0.003)$, this means that it supports the hypothesis $\mathrm{H} 1$ and $\mathrm{H} 2$. Furthermore, retention affects positive and significant task performance $(\beta=0.369, p<$ 0.001) which means confirming the $\mathrm{H} 2$ hypothesis. Retention has a positive and significant effect on contextual performance ( $\beta=0.369, p<0.001$ ), thus the $\mathrm{H} 4$ hypothesis is also accepted.

Table 5. The Hypothesis Testing of Model 1

\begin{tabular}{|c|c|c|c|}
\hline Hypothesis & Path & $\begin{array}{c}\text { Path } \\
\text { Coefficients }\end{array}$ & P-value \\
\hline H1 & Seleksi $\longrightarrow$ Task Performance & 0.345 & $0.017^{*}$ \\
\hline $\mathrm{H} 2$ & $\begin{array}{l}\text { Seleksi } \longrightarrow \text { Contextual } \\
\text { Performance }\end{array}$ & 0.369 & $0.003 * *$ \\
\hline H3 & Retensi $\longrightarrow$ Task Performance & 0.560 & $<0.001$ \\
\hline H4 & $\begin{array}{l}\text { Retensi } \longrightarrow \text { Contextual } \\
\text { Performance }\end{array}$ & 0.446 & $<0.001$ \\
\hline
\end{tabular}

The results support the proposition of STIFInbased HR management, namely to recruit and select employees based on the personality type which is inherent in a person. Thus, they feel what is done and the work is suitable and in accordance with their character and personality type (Poniman and Hadiyat, 2015). The placement of employees by the personality type will result in high productivity and performance. This is because the employee feels comfortable and there is a match between his/her work and personality type. This study is also in line with the results of the study of Jounda, et al., (2016) where recruitment and selection can significantly predict employee performance (Jouda, et al., 2016). Specifically related to the application of STIFIn's personality type in predicting performance, the study is in line with Rafianti's research, et al. (2016) where STIFIn intelligence types can predict results in high school students' mathematical abilities.

Several studies related to systems and practices of human resource management that consider aspects of personality have proven to have a significant effect on employee's performance (Wambua and
Karanja, 2016). Likewise, a research conducted by Hozler et al., (2004) reported that differences in personality characteristics of workers are related to performance and retention. The placement of workers based on personality types will affect their survival to stay involved and work in a program or activity. The study of Paradis and Usui (1987) on hospital nurses reported that volunteers who scored well on tests which measure empathy, anxiety tendencies and "euthanasia", significantly predicted volunteers' ability to help patients, as well as the ability to understand dying patients and their families, as well as the desire to continue to participate in the program voluntarily.

In applying STIFIn personality types, employee selection and retention adjusted to personality types significantly influence both task performance and contextual performance. For this reason in the workforce planning, all types of work need to be mapped and grouped based on STIFIn personality characteristics, so that the search or recruitment of workers is tailored to the placement that needs workers who have been mapped to the needs of STIFIn personality 
types. Further, the companies can provide appropriate retention programs according to their personality types.

\section{Model 2}

\section{Outer Model Test Results}

In the next step, the researcher analyzes model 2, which is an analysis of the secondorder construct indicator. It means the analysis is carried out from latent constructs and dimensions. Table 6 is the result of the second level confirmatory factor analysis (second CFA order). Based on the results of the second-order confirmatory factor analysis below, it can be seen that the forming indicators (dimensions) of all latent constructs are valid with the resulting factor loading value of $>0.7$. Furthermore, the AVE value for each very good latent construct $>0.5$ means that it meets the criteria for convergent validity.

Table 6. Second-Order of CFA

\begin{tabular}{|c|c|c|c|c|c|c|c|}
\hline Dimensi & $\begin{array}{l}\text { Factor } \\
\text { Loading }\end{array}$ & $\begin{array}{c}\text { Latent } \\
\text { construct }\end{array}$ & $\begin{array}{l}\text { Composite } \\
\text { Reliability }\end{array}$ & $\begin{array}{l}\text { Cronbach } \\
\text { 's Alpha }\end{array}$ & AVE & $\begin{array}{c}\text { Squar } \\
\text { e root } \\
\text { AVE }\end{array}$ & $\begin{array}{c}\text { Full } \\
\text { collin } \\
\text { VIF }\end{array}$ \\
\hline Selection & 0.892 & \multirow[t]{2}{*}{ HR STIFIn } & \multirow[t]{2}{*}{0.901} & \multirow[t]{2}{*}{0.781} & \multirow[t]{2}{*}{0.82} & \multirow[t]{2}{*}{0.905} & \multirow[t]{2}{*}{2.643} \\
\hline Retention & 0.918 & & & & & & \\
\hline $\begin{array}{l}\text { Task } \\
\text { Performance }\end{array}$ & 0.939 & \multirow[t]{2}{*}{$\begin{array}{c}\text { Job } \\
\text { Performance }\end{array}$} & \multirow[t]{2}{*}{0.934} & \multirow[t]{2}{*}{0.859} & \multirow[t]{2}{*}{0.876} & \multirow[t]{2}{*}{0.936} & \multirow[t]{2}{*}{2.643} \\
\hline $\begin{array}{l}\text { Contextual } \\
\text { Performance }\end{array}$ & 0.933 & & & & & & \\
\hline
\end{tabular}

Likewise, the Composite Reliability (CR) and Cronbach's Alpha $(\alpha)$ values are $>0.7$, meaning that the reliability values generated by each latent construct are also very good and meet internal consistency reliability. The value of Full Collinearity VIF for each latent construct is also very good, which is $<3.3$ so there is no collinearity problem in the model.
Furthermore, reflective indicators forming latent constructs in the study will also be tested discriminant validity. One way to look at discriminant validity is by comparing the correlation between variables with the square root of variance extracted (the value of the square root AVE). Table 7 describes model 2's discriminant validity of this study.

Table 7. Discriminant Validity Model 2

\begin{tabular}{lcc}
\hline & $\begin{array}{l}\text { HR } \\
\text { STIFIn }\end{array}$ & $\begin{array}{l}\text { Job } \\
\text { Performance }\end{array}$ \\
\hline HR STIFIn & $0.905^{*}$ & \\
\hline Job & 0.788 & $0.936^{*}$ \\
Performance & & \\
\hline
\end{tabular}

From table 7, it can be seen that the correlation value between variables (latent construct) is below the AVE square root value (see with a diagonal line, marked and * '). Thus, it can be concluded that all variables meet discriminant validity criteria and can be said to be a very good model.

Inner Model Results (Model-2)

Based on the results of the general result of SEM-PLS, it is known that the model has a 
good fit, where the P-value for Average Path Coefficient (APC), Average R-squared (ARS), and Average Adjusted R-squared (AARS) < 0.001 with the value $A P C=0.788, A R S=0.622$, and the value of AARS $=0.612$. Likewise, with the value of Average Full Collinearity VIF (AFVIF), the ideal value is AFVIF $=2.643(<3.3)$, which means that there are no multicollinearity problems. The resulting GoF is $0.726>0,36$ which means that the model fit is good. For the Symson's Paradox (SPR) index, R-squared Contribution Ratio (RSCR), Statistical Suppression Ratio (SSR), and Nonlinear Bivariate Causality Direction Ratio (NLBCDR) produce values equal to 1 , which means there are no causality problems in the model.

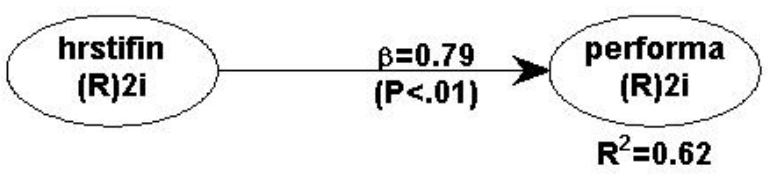

Figure 3. Structural Model Analysis - Model 2

The results showed that the adjusted Rsquared was 0, $612(61.2 \%)$, which means that the large dependent latent variable (job performance) was explained at $61.2 \%$ by independent latent variables (HR STIFIn) and the remaining $38.8 \%$ explained by other variables outside the model. The $\mathrm{Q}$-squared value (Q2) is generated for the dependent variable (endogenous) $>0$, which is $\mathrm{Q} 2=$ 0.617, which means that the model has predictive relevance.

Tabel 8. Test of Hypothesis Model 2

\begin{tabular}{cccc}
\hline Hypothesis & Path & Path Coefficients & $P$-value \\
\hline H5 & $\begin{array}{c}\text { HR STIFIn Job } \\
\text { Performance }\end{array}$ & 0.788 & $<0.001$ \\
& & & \\
\hline
\end{tabular}

Figure 3 and table 8 explain the results of hypothesis testing (path analysis model 2), which shows that the STIFIn HR results have a positive and significant effect on job performance $(\beta=0.788, p<0.001$ ), thus the results support the hypothesis $\mathrm{H} 5$. The research is in line with other previous researches where the implementation of HR management practices is very important to improve organizational results. Recruitment and selection practices, career management and promotion, teamwork, employee responsibilities, autonomy, complaint resolution mechanisms, and benefit plans for employees, are reported to be positively related to organizational commitment
(Caldwell, Chatman and O'Reilly, 1990). Organizational commitment itself is a predictor of employee performance (Khan, et al., 2010; Lam, et al., 2013; Memari, et al., 2013; and Cesario and Chambel, 2017). Direct studies on the effect of effective HRM practices on job performance reported significant influences on recruitment and selection, training, employee involvement, employee retention, and work relationship completion, but there was no significant effect on service management functions (Tabiu and Nura, 2013). The results of testing in Model 2 in this study can provide a reference for the implementation of HR management practices, especially those using personality type 
schemes in employee placement, namely STIFIn-based HR management practices that significantly influence employee performance.

\section{Research Limitations and Future Research Directions}

This study has limitations in terms of the number of respondents. Subsequent research can be done again with a larger number of respondents so that they can see the influence of demographic factors of each intelligence machine on the relationship between HR STIFIn Practice and Job performance. This is expected so that the theory can be built more mature and perfect in the future.

\section{CONCLUSIONS}

Based on the results of the hypothesis test $\mathrm{H} 1$ and $\mathrm{H} 2$ show that STIFIn HR-based selection has a positive and significant effect on job performance, namely task performance and contextual performance. Then based on the results of the hypothesis test $\mathrm{H} 3$ and $\mathrm{H} 4$ indicate that retention based on STIFIn HR has a positive and significant effect on task performance and contextual performance. Meanwhile, based on the results of the hypothesis test $\mathrm{H} 5$, shows that the STIFIn HR practice has a positive and significant effect on job performance. Likewise, the indicators of each exogenous and endogenous variable have a significant effect. Empirically STIFInbased HR management (HR STIFIn), namely selection has a significant influence on task performance and contextual performance, meaning that the selection of employees using the STIFIn personality type scheme will positively influence employee performance. If the employee selection and placement or assignment are considered to the personality type, the employee will thus show high overall performance, both task performance or contextual performance.

STIFIn-based HR management practices in Model 2 testing shows a significant effect on performance. This can be interpreted that the implementation of STIFIn-based HR management-if implemented as a wholewill have a higher effect on employee performance. STIFIn's-based HR management practices, namely selection, and retention predict $78.8 \%$ of employee performance. The research empirically supports the STIFIn personality theory in human resource management practice. In line with this research is the research conducted by Arifin and Gunadi (2017) regarding the explanation of STIFIn personality circulation theory. This personality circulation theory explains the need to map the personality types of teachers and students to achieve successful teaching and learning processes. Moreover, the research conducted by Rafianti and Pudjiastuti (2017) reported the STIFIn personality type as a predictor of student success in mathematics. This study shows that the mapping of employees based on personality types will greatly predict the success of team performance.

For the implementation, the research provides recommendations for an effort to improve job performance, the organization or company must pay attention to the variables that affect job performance, and in the research, it has been shown that the practice of HR STIFIn can influence job performance strongly. The things that can be done are (1) Providing information about the organization to applicants during the recruitment process, so that prospective employees know the goals, vision, and mission of the organization; (2) Increasing employee involvement in the process of teamwork improvement and problem-solving, to create a climate of good cooperation, despite different personalities; (3) Finding the right solution in accordance with the intelligence engine to map which employees can handle extra work and show strength when they are faced with pressures. 
Yayan Hadiyat: Applying The Theory of ...

\section{REFERENCES}

Alindra, A.L. (2018). Kajian Aksiologi Metode Stifin dalam Pemetaan Mesin Kecerdasan Manusia. Jurnal Filsafat Indonesia, 1(1).

Arifin, I., and Gunadi, I. (2017). Leadership of Ece Principal in Growth Character Through Stifin Method in Kindergarten. Advances in Social Science, Education and Humanities Research (ASSEHR), 66, 295-300.

Askarian, N., and Eslami, H. (2013). The Relationship between Personality Traits and Job Performance (Case Study: Employees of the Ministry of Education of Kerman), 322- 335.

Barrick, M. and Mount, M. (1991). The Big Five Personality Dimensions and Job Performance: A Meta Analysis. Personnel Psychology, 44, I-29.

Boudreau, J.W., and Ramstad, P.M., (2005), Talentship, Talent Segmentation, and Sustainability: A New HR Decision Science Paradigm for A New Strategy Definition. Human Resource Management, 44(2), 129-136.

Bhatti, M.A., et al. (2013). Bhatti, Effects of Individual Characteristics on Expatriates' Adjustment and Job Performance. European Journal of Training and Development, 37(6), 544-563.

Becker, B.E., and Huselid, M.A.. (1998). High Performance Work System and Firm Performance: A Syntesis of Research and Managerial Implications.

Borg, M. O., and Shapiro, S. L. (1996).

Personality Type and Student

Performance in Principles of Economics. The Journal of Economic Education, 27(1), 3-25.

Campbell, J. P., et al. (1993). A Theory of Performance. In N. Schmitt \& W. C. Borman (Eds.), Personnel selection in organizations (pp. 35-70). San Francisco: Jossey-Bass.

Chirumbolo, A. (2014). The Impact of Job Insecurity on Counterproductive Work
Behaviors: The Moderating Role of Honesty-Humility Personality Trait. The Journal of Psychology Interdisciplinary and Applied, 149(6), 554-569.

Cunha, Da, A.D., and Greathead, D. (2007). Does Personality Matter? An Analysis of Code-Review Ability: Developing A Better Understanding of The Mental Processes Leading to Success or Failure in Code Review. Communication of the Acm, 50(5).

Ciorbeaa, I., and Pasaricaa, F. (2012). The Study of the Relationship Between Personality and Academic Performance. Procedia - Social and Behavioral Sciences, 78, 400-404. https://doi.org/10.1016/j.sbspro.2013.0 4.319

Delery, J.E., and Shaw, J.D. (2001). The Strategic Management of People in Work Organizations: Review, Synthesis, and Extension. Research in Personnel and Human Resources Management, 20, 165-197. https://doi.org/10.1016/S07427301(01)20003-6.

Furnham, A., and Stringfield, P. (1993). Personality and Work Performance: Myers-Briggs Type Indicator Correlates of Managerial Performance in Two Cultures. Personality and Individual Differences, 14(1), 145-153. Doi:10.1016/0191-8869(93)90184-5

Gregory M. Hurtz, G.M., and Donovan, J.J., (2000). Personality and Job Performance: The Big Five Revisited. Journal of Applied Psychology, 85(6), 869-879.

Glaister, A.J., et al. (2016). HRM and Performance - The Role of Talent Management as a Transmission Mechanism in an Emerging Market Context. Human Resources Management Journal, 28(1), 148-166. https://doi.org/10.1111/17488583.12170 . 
Holzer, H. J., et al. (2004). Job Performance and Retention among Welfare Recipients. Social Service Review, 78(3), 343-369. doi:10.1086/421917

Hassan, S. (2016) Impact of HRM Practices on Employee's Performance. International Journal of Academic Research in Accounting Finance and Management Sciences, 6(1), 15-22.

Hair, J. F., et al. (2014). A Premier Partial Least Squares Structural Equation Modeling (PLS-SEM). LoS Angeles: SAGE Publications, Inc

Herrmann, N. (1989). The Creative Brain. Lake Lure. Volume25 Number 4 Fourth Quarter. NC: BrainBooks.

Huselid, M.A. (1995). The impact of human resource management practice on turnover, productivity, and corporate financial performance. Academy of Management Journal, 38(3), 635-672.

Hough. (1992). The 'Big Five' Personality Variables--Construct Confusion: Description Versus Prediction. Human Resource, 5(1\&2), 139-155.

Hiltrop, J.M., (1996). The impact of human resource management on organisational performance: Theory and research.

Jouda, Ali A., et al. (2016). The Impact of Human Resource Management Practices on Employees Performance: The Case of Islamic University of Gaza in Palestine. International Review of Management and Marketing, 6(4), 1080-1088.

Jung, C.G. (1946). Psychologycal Type or The Psychology of Individual. London: International Library of Psychology, Kegan Paul, Trench, Trubner \& Co, Ltd.

Kehoe, R. R., and Wrigth, P. M. (2010). The Impact of High-Performance Human Resource Practices on Employees' Attitudes and Behaviors. Journal of Management, 20(10), 1-26.

Koopmans, L. (2014). Measuring Individual Work performance. Netherlands: CPI Koninklijke Wohrmann, Zutphen.
Koch, M.J., and R.G.McGrath. (1996). Improving labor productivity: Human Resource Management Policy do Matter?. Strategic Management Journal, 17, 335-354 (I 996).

Lado, M., and Alonso, P. (2017). The FiveFactor Model and Job Performance in Low Complexity Jobs: A Quantitative Synthesis. Revista de Psicología Del Trabajo y de Las Organizaciones, 33(3), 175-182. doi:10.1016/j.rpto.2017.07.004.

Leena, P., and Kirupa, M. (2016). The Impact of Personality Traits on Job Performance in the Context of Mobile Social Networking. International Journal of Research in IT and Management (IJRIM), 6(7), 41-48.

Lado, A.A., Wilson, M.C.. (1994). Human Resource Systems and Sustained Competitive Advantage: A CompetencyBased Perspective. Academy of Management Review, 19(4), 699-727.

Latan, H., and Ghozali, I. (2017). Partial Least Squares (Konsep, Metode dan Aplikasi Menggunakan Program WarpPLS 5.0). Third Edition. Semarang: Badan Penerbit Universitas Diponegoro.

Mi-Ran Kim, M.R., and Han, S.J. (2014). Relationships between the Myers-Briggs Type Indicator Personality Profiling, Academic Performance and Student Satisfaction in Nursing Students. International Journal of Bio-Science and Bio-Technology, 6(6), 1-12. http://dx.doi.org/10.14257/ijbsbt.2014. 6.6.01.

MacLean, P. (1990). The Triune Brain in Evolution: Role in Paleocerebral Functions. New York and London: National Institute of Mental Health Bethesda, Mryland, Plenum Press.

MacDuffie, J.P. (1995). Human Resource Bundles and Manufacturing Performance: Organizational Logic and Flexible Production Systems in the 
Yayan Hadiyat: Applying The Theory of ...

World Auto Industry. Industrial and Labor Relations Review, 48(2).

Mazni, O., et al. (2010). Analyzing Personality Types to Predict Team Performance. International Conference on Science and Social Research (CSSR 2010), December $5-7,2010$, Kuala Lumpur, Malaysia.

Mundiri, A., and Zahra, I. (2017). Implementasi Metode STIFIn dalam Meningkatkan Kemampuan Menghafal Al-Qur'an di Rumah Qur'an STIFIn Paiton Probolinggo. Jurnal Pendidikan Agama Islam, 5(2), 201-223. DOI: http://dx.doi.org/ 10.15642/jpai.2017.5.2.201-223

Paradis, L. F., and Usui, W. M. (1987). Hospice Volunteers: The Impact of Personality Characteristics on Retention and Job Performance. The Hospice Journal, 3(1), 3-30. doi:10.1080/0742969x.1987.11882578

Pfeffer, J. (1994). Competitive Advantage Through People. Boston: Harvard Business School Press.

Poniman, F. and Amalia, N. (2020). A Grand Theory of STIFIn Personality: Basic Function Theory Revisted. International Journal of Pshycocial Rehabilitation, 24(5).

Poniman, F. (2009). STIFIn Personality. Bekasi: Yayasan STIFIn.

Poniman, F. and Hadiyat, Y. (2015), Manajemen HR STIFIn (Terobosan untuk Mendongkrak Produktivitas. Jakarta: PT Gramedia Pustaka Utama.

Porter, M. E. (1980). Competitive Strategy. New York: Free Press

Ramawickrama, J., et al. (2017). Synthesis Towards The Construct of Job
Performance. International Business Research, 10(10).

Salgado, Jesus F. (1997). The Five Factor Model of Personality and Job Performance in the European Community. Journal of Applied Psychology, 82(1), 30-43. doi: 10.1037//0021-9010.82.1.30

Schuler, R.S., and Jackson, S.E. (1995). Understanding HRM in The Context Of Organization And Environment. Anna Rev. Psychol, 46, 237-64.

Tett, R.F., et al. (1991). Personalitymeasure as Predictos Measures of Job Performance: Meta-analytic Review. Personnel Psychology, 44.

Tabiu, A., et al. (2016). Examining the Link Between HRM Practices and Employees' Performance in Nigerian public sector. Management Science Letters, 6, 395408.

Truxillo, D. M., et al. (2016). Psychology and work: Perspectives on industrial and organizational psychology. Oxfordshire: Routledge.

Wambua, S.M., and Karanja, K. (2016). Effect of Human Resource Management Practices on Employee Performance in Commoercial Banks in Nairobi County, Kenya. The Journal of Management, 3(2), 213-232.

Wright, P.M., and Boswell, W.R. (2002). Desegregating HRM: A Review and Synthesis of Micro and Macro Human Resource Management Research. Journal of Management, 28(3), 247-276, https://doi.org/10.1177/014920630202 800302. 